\title{
鎖国してはいけない
}

科学面での国際協調こそが、生物テロに対する最高の防御法である。

\section{Thomas May}

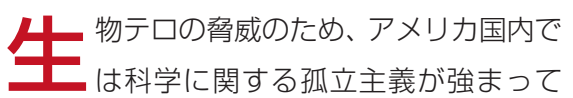

いる。生物兵器に関わる機密的情報の公表や 「高品質な」研究用生物剂の入手、特定国家出 身科学者の養成に関する新たな規制がその例 である。科学活動の制限は核兵器の拡散に対 しては合理的かもしれないが、生物テロに対 するアメリカの国防には逆効果となってしま う可能性がある。

生物テロは、生物剤攻撃による被害が攻撃 そのものに限定されずに、疾患が広がると考 えられる点で、独特の脅威を与えるものであ る。いかなる場所や地域、国ですら、感染症 を封じ込めるのは容易なことではない。世界 保健機関 (WHO) は、2003 年の重症急性呼吸 器症候群(SARS) など世界的な疾患の流行に 関して、多くの例を詳細に記録している。中 国南部で発生して 30 力国近くに広がった SARS では、9 カ月間で感染者数が8,098人に のぼり、774人が亡くなった $1 。$

生物テロ攻撃では、使用される生物剤と攻 撃法が最大効果を目指したものになると考え られ、自然発生的な疾患である SARS をはる かにしのぐ被害が出る可能性が高い。疾患の 発生が迅速に把握されそうもない地域で生物 剂が使用された場合、封じ込めが困難なほど の強力な足場がひとたび築かれれば、国際的 な人の往来の便を利用して「標的」国に疾患を 広げることが可能となるであろう。このた め、感染症発生の把握亡封じ込めのための国 際的対策を強化するなど、生物テロの喎威が もつ国際的広がりに留意することが特に重要 である。

現在までのところ、国家安全保障の專門家 は、この種の攻撃の危険性はかなり低いと考 えている2。テロリスト自身を含む標的外の人 に危害を及ぼすという無差別性ゆえに、生物 テロは支持が得られないであろうと思われて いた。しかしこの分析は、合理的な自己利益
に基づくテロリスト行動を予想した陳腐なも のであり、現代のテロリストにそのまま当て はめることはできない。

現実的理由から人的被害を抑えようとする テロリストは多いが、新興テロリスト集団は 市民の支持をさほど得ようとせず、過激な手 段をもっていることが多い。その上、今日の テロリストは自爆(および無幸の市民の殺戮) の意志を示して目的を達成するのが常態化し ている。

このことに鑑みて、アメリカは生物テロの 予防や生物テ口攻撃への対応と封じ込めに最 適な戦略を推進しているだろうか。本土防衛 優先事項 ${ }^{3}$ では、テロリストに潜在的生物兵器 を渡さないようにするための外交、情報、法 執行 (テロリストの資金ネットワーク遮断を 含む)、および国境管理という手段に力点が置 かれている。いずれも有効な施策ではあるが、 現代の生物テロの国際的 広がりやアメリカへの最 も現実的な攻撃経路に対 処するものとしては不十 分である。また、アメリカ 社会の「開放的」性質がテ 口への脆弱さを生み出し ているという考え方も広 く信じられている3。だが 生物テロ攻撃に備える場 合、開放的な研究教育体制 はアメリカの国防能力の なかで最も重要なものの ひとつである。安全保障に 関して新しい考え方が強 く求められている。

生物テロの脅威が真に 国際的なものであるとい う認識をもって、アメリカ は外国の科学者や医療従 事者、公衆衛生要員の養成 に主導的役割を果たし、疾
患発生の把握と封じ込めに関する国際的態勢 を構築しなければならない。これはさまざま なレベルで行われる必要がある。まず、国内 外の公衆衛生要員を十分に支援ならびに養成 することができるよう、米疾病予防管理セン ター(CDC : ジョージア州アトランタ)の態勢 を充実する必要がある。CDCにとってその種 の支援は長年の重点事項であったが、これを 拡充するだけの余力がなく、2003年に外交問 題評議会 ${ }^{4}$ は国内要員の養成でさえ「極度の予 算不足」であると発表している。次に、感染症 の監視と封じ込めに関する体制整備という WHOの取り組みを、アメリカにとっての優 先事項としなければならない。生物テロの性 格は特異なものであり、国際的健康管理の実 際的体制整備が従来型外交と同等の戦略的重 要性をもっている。

おそらく最も重要なのは、アメリカの学術

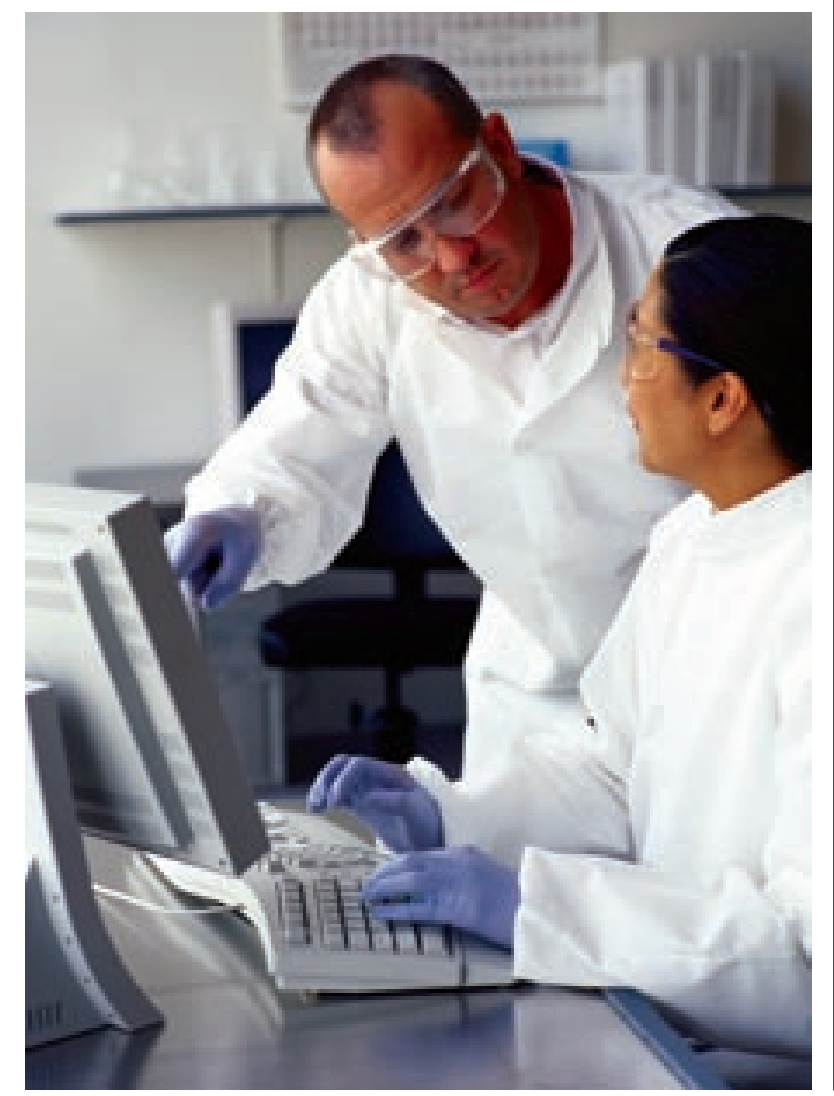

